\title{
MODELING THE TRANS-ATLANTIC TRANSPORTATION OF SAHARAN DUST
}

\author{
Tsikerdekis A. ${ }^{1}$, Zanis P. ${ }^{1}$, Steiner L.A. ${ }^{2}$, Amiridis V. ${ }^{4}$, Marinou E. ${ }^{4}$, \\ Katragkou E. ${ }^{1}$, Karacostas Th. ${ }^{1}$ and Solmon . $^{4}$
}

${ }^{1}$ Aristotle University of Thessaloniki, Department of Meteorology and Climatology, 54124,

Thessaloniki,Greece,tsike@geo.auth.gr,zanis@geo.auth.gr,katragkou@geo.auth.gr, karac@geo.auth.gr

${ }^{2}$ Atmospheric, Oceanic and Space Sciences, University of Michigan, Ann Arbor, MI 48109, USA, alsteine@umich.edu

${ }^{3}$ Institute for Astronomy, Astrophysics, Space Application and Remote Sensing, National Observatory of Athens, 15236 Athens, Greece,vamoir@noa.gr, elmarinou@noa.gr

${ }^{4}$ Earth System Physics Section, The Abdus Salam International Centre for Theoretical Physic, 34100 Trieste, Italy, fsolmon@ictp.it

\begin{abstract}
In the present study we are simulating the trans-Atlantic transport of dust from Sahara to the South-Central America, using the regional climate model RegCM4 and its online dust scheme, for the year 2007. The simulated horizontal and vertical distributions of the mineral dust optical properties were evaluated against the LIVAS CALIPSO satellite dust product. The Trans-Atlantic dust transport is simulated adequately with RegCM4, but there are some spatial discrepancies. Dust optical thickness is overestimated in the eastern Sahara throughout the year by 0.1-0.2, while near the gulf of Guinea is underestimated during winter and spring. Although RegCM4 dust plume is located southern on winter and spring, it doesn't spatially match the dust optical thickness of LIVAS. In summer and autumn the vertical distribution of dust between $3-4 \mathrm{~km}$ during the Trans-Atlantic transport is simulated by the model adequately up to $30^{\circ} \mathrm{W}-40^{\circ} \mathrm{W}$ longitude. However, during winter-spring RegCM4 misplaces dust loading into higher altitude. Finally, we discuss some possible reasons and mechanisms that might be responsible for the differences between the model and the observations.
\end{abstract}

Keywords: RegCM4, LIVAS, Aerosol.

\section{Пєрíi $\eta \psi \eta$}

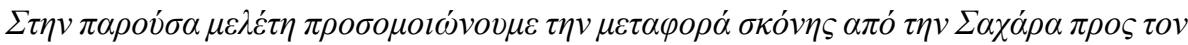

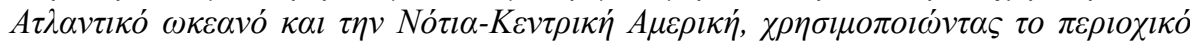

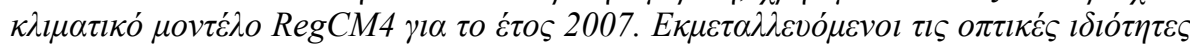

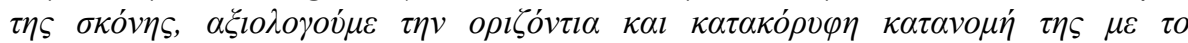

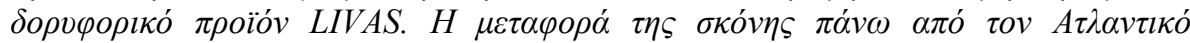

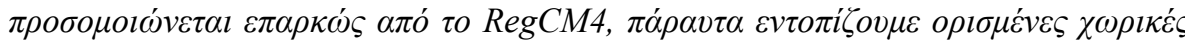

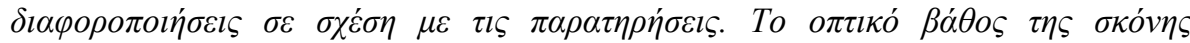

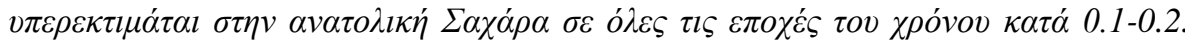

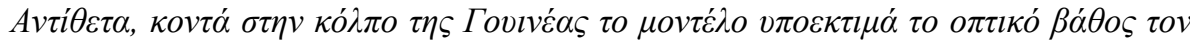




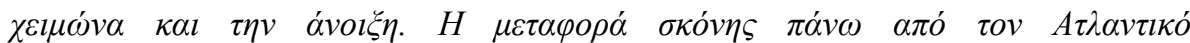

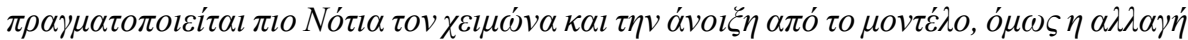

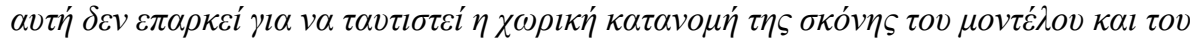

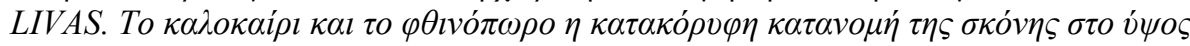

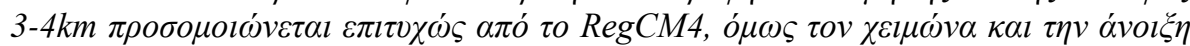

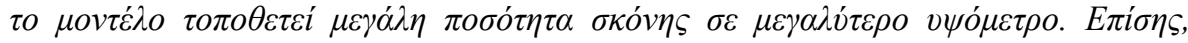

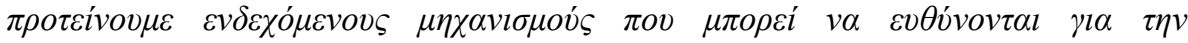

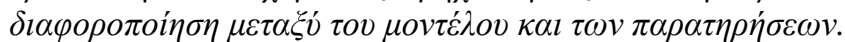

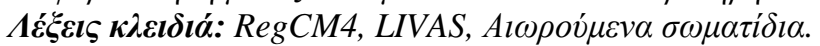

\title{
1. Introduction
}

Mineral dust is the most abundant atmospheric aerosol in the atmosphere. Natural dust is emitted in episodic events over arid and semi-areas that are concentrated between $15^{\circ}-30^{\circ}$ latitude in both hemispheres. The largest source of mineral dust is the Sahara desert (Huneeus et al., 2011), a vast arid region in the Northern Africa that receives less than $200 \mathrm{~mm}$ year-1 of precipitation (Engelstaedter et al., 2006). Between the zone $40^{\circ} \mathrm{N}-10^{\circ} \mathrm{S}$ latitude, dust is transported by the easterly trade winds though the Atlantic ocean to the American continent affecting the radiation budget of the planet with numerous direct (Tegen, 2003) and indirect mechanisms (Bangert et al., 2012). Dust that is deposited in the Atlantic and to Amazon forest provides crucial nutrients that are essential for the marine (Mahowald et al., 2005) and forest ecosystems (Bristow et al., 2010). Dust may also affect the growth and intensity of strong weather convective system near the equator, that eventually may evolve into tropical cyclones, known as easterly waves (Zipser et al., 2009).

Dust particles size in the atmosphere ranges from $0.01 \mu \mathrm{m}$ to $100 \mu \mathrm{m}$ (Knippertz and Stuut, 2014). The atmospheric lifetime of dust particles controls the evolution of dust size distribution as they move downwind (Mahowald et al., 2014). Large particles, due to their size and weight, are concentrated close to the ground and they are quickly removed from the atmosphere through dry deposition processes. Since they have such a short atmospheric life, they are located mainly close to the source regions. On the other hand, small particles, usually smaller than $2.5 \mu \mathrm{m}$, can be uplifted and remain on the mid-troposphere while they are being transported for thousands kilometers away from their source regions. Although size and density of dust particles are the key factors that force sedimentation, particle shape can have a big impact both on their deposition velocity and optical properties (Formenti et al., 2011).

Previous researches have highlighted the almost constant dust plume that begins on the western coast of Sahara and floats over the North Atlantic ocean reaching the South-Central America (Chin et al., 2014; Kim et al., 2014; Yu et al., 2015). Although the dust plume covers the largest part of the North Atlantic ocean all year long, it has some spatial-seasonal characteristics. Backscattering measurements of dust from the satellite instrument CALIOP showed that the dust transport peaks at summer and weakens in autumn. In both of these seasons dust concentration reach its highest point between $10^{\circ} \mathrm{N}-20^{\circ} \mathrm{N}$ latitude. Contrary in winter and spring dust transport shifts southward close to the equator between $0^{\circ}$ to $10^{\circ} \mathrm{N}$ latitude. These seasonally differences extend also on the vertical distributions of dust that looms over the North Atlantic (Yu et al., 2015).

During the trans-Atlantic dust transfer Million tons (Tg) of dust emitted by Sahara are deposited over the North Atlantic and the South and Central America every year. Though the exact number of the deposited dust for these regions it is still debated (Kaufman, 2005; Koren et al., 2006; Ridley et al., 2012), partly because satellite products do not measure directly deposition fluxes and the groundbased station network that actually measure dust deposition fluxes is spatially sparse, especially over the ocean. Moreover, the emitted dust from Sahara greatly differs between models by a factor of five (from 422 to $2025 \mathrm{Tg}$ year-1) when average for the same region (Kim et al., 2014). Thus, deposition and transportation of simulated dust may not be representative. 


\section{Data}

\section{1. $\operatorname{RegCM4}$}

The Regional Climate Model (RegCM) is a space limited numerical model which was developed at the National Center of Atmospheric Research (NCAR) and the Abdus Salam International Center for Theoretical Physics (ICTP). In the present study we are using the 4th version of the model, RegCM4 (Giorgi et al., 2012). Land-Atmosphere interactions are analyzed with the BiosphereAtmosphere Transfer Scheme (BATS) (Dickinson et al., 1993), while there is a recently implemented alternative option to use the Community Land Model (CLM4.5) (Oleson et al., 2013). The radiation transfer scheme used on RegCM4 is based on the NCAR Community Climate Model version 3 (CCM3) (Kiehl et al., 1996) as introduced by (Giorgi et al., 1999). Recently the correlatedk Rapid Radiation Transfer Model (RRTM) was implemented (Mlawer and Clough, 1997; Mlawer et al., 1997).

The online dust emission scheme (Marticorena and Bergametti, 1995; Alfaro et al., 1997; Gong, 2003; Zakey et al., 2006) depends on the simulated surface wind shear and surface attributes. Dust ascends from the ground when the surface wind velocity exceeds a specified wind speed threshold known as threshold friction velocity. Surface roughness and soil moisture, which are essential for the calculation of threshold friction velocity, are provided by the surface scheme BATS (Zakey et al., 2006). Following the calculation of the dust mass emission fluxes, the tracer transport equation is applied for each transported bin (Solmon et al., 2006). Removal processes through dry deposition and wet deposition (washout) are included in the model (Zakey et al., 2006). The optical properties of dust are calculated for every size bin and each spectral band of the radiation scheme in use (CCSM or RRTM) using Mie theory. The spectral band closer to 550nm (350-640nm in CCM3) is used for evaluation against most satellite derived aerosol optical depth and extinction products.

The majority of climate models use a log-normal fitting to represent the particle size distribution of the transported dust bins. Though, it is favourable to use physical based characteristics to define the size groups of dust bins to improve the evaluation against observational data (Formenti et al., 2011). A physical based iso-gradient method was developed by (Foret et al., 2006) which aggregates dust size groups according to their deposition velocity. This iso-gradient method was implemented into RegCM4 that now simulates 12 transport dust bins.

\section{LIVAS}

LIVAS, which stands for "LIdar climatology of Vertical Aerosol Structure for space-based lidar simulation studies" (Amiridis et al., 2015), is an effort to derive a 3-dimentional global climatic dataset utilizing the CALIPSO measurements, funded by the European Space Agency (ESA). CALIPSO is capable to obtain high resolution profiles of the attenuated backscatter of aerosols and clouds at $532 \mathrm{~nm}$ and $1064 \mathrm{~nm}$. It can retrieve aerosol optical properties below optically thin clouds, in clear skies and above clouds while it cannot detect aerosol layers below optically thick low-level clouds (Winker et al., 2009). The LIVAS database is available globally, in a mean monthly basis, over $1^{\circ} \times 1^{\circ}$ horizontal resolution. The vertical resolution is the same as CALIPSO L2 vertical resolution and varies from $60 \mathrm{~m}$ between $-0.5 \mathrm{~km}$ and $21 \mathrm{~km}$ to $180 \mathrm{~m}$ above $21 \mathrm{~km}$ (Amiridis et al., 2015). In this work we use the specialized LIVAS pure dust product, which includes the extinction coefficient of pure dust, calculated from the dust percentage of "dust" and "polluted dust" aerosol subcategories of CALIPSO (Amiridis et al., 2013).

The LIVAS extinction dust product is corrected for the Lidar Ratio (LR) based on multi-year measurements performed by the ground-based lidar stations of the EARLINET lidar network. The LR value may vary a lot even for aerosols of the same group-type. The LR of dust particles depends on their refractive index. The refractive index values rely upon the composition of dust and most importantly on the relative proportion of clay-sized mineral illite in dust (Schuster et al., 2012). Thus, regions with different physiochemical dust characteristics lead to different LR values. The 0.3.1 
version of LIVAS separates the globe into three regions depending on the LR assumption they use. The regions specified usually receive dust loading from known dust sources with specific physiochemical composition, hence similar LR value.

\section{Results}

Dust Optical Depth (DOD) and Dust EXtinction coefficient (DEX) for each layer of RegCM4 was assessed using the LIVAS dust product. Since those two datasets were produced based in different spatiotemporal considerations, some necessary pre-processing steps were required before the evaluation. The simulated spatial fields were firstly interpolated into the $1^{\circ} \times 1^{\circ}$ grid of LIVAS in order to calculate directly the differences between the two datasets. Furthermore, since LIVAS was produced using the attenuated backscatter measurements of the CALIOP instrument upon the nongeostationary satellite CALIPSO, the spatial-temporal fields are not consecutive. Dust optical measurements were available only when the satellite orbit and the cloud vertical distribution in the atmosphere were favourable. Thus, a spatiotemporal mask was produced using the exact UTC time and grid cell location specified in LIVAS. The UTC times specified in the metadata of LIVAS were interpolated to the closest timestep of the model. The spatial-temporal mask of LIVAS was applied in the 6-hourly RegCM4 data and thereafter we have calculated the monthly, seasonal and yearly means.

Figure 1 depicts the yearly DOD mean for 2007 as it was processed for LIVAS, simulated by RegCM4 and their difference. The model clearly exhibits some spatial discrepancies compared to LIVAS. It overestimates the DOD over the Eastern Sahara by 0.1-0.2 and underestimates it over the Northern Africa land mass located just above of the gulf of Guinea. On the other hand it simulates fairly well the dust plume extending from the western coast of Northern Africa towards Atlantic.
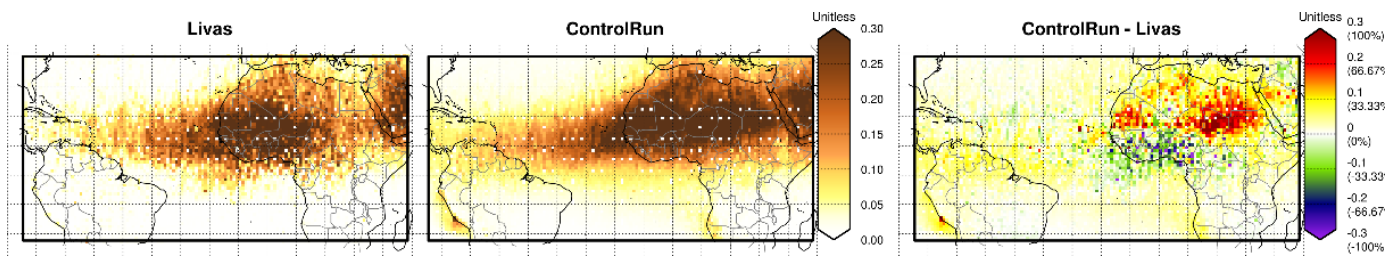

Figure 1 - Dust optical depth for Livas at 532nm and RegCM4 at 550nm for the year 2007.

As it was highlighted previously, the Atlantic dust plume is driven by some strong seasonal characteristics. Therefore, in Figure 2 we are exploring the seasonal DOD over our domain. The distinct underestimation close to gulf of Guinea highlighted in Figure 1 prevail over winter and spring while DOD is overestimated over Eastern Sahara all year long. During winter and especially spring, the Atlantic dust plume moves southward (Yu et al., 2015) closer to the equator, but most of the global/regional climate models cannot accurately simulate that change (Prospero et al., 2014). Although RegCM4 shows a slight southward transfer in winter-spring across the Atlantic compare to summer-autumn, it is not enough to accurately simulate the observed spatial pattern of LIVAS. Like most of the models, RegCM4 simulates the trans-Atlantic transport better during summer than in winter (Huneeus et al., 2011).

In order to understand and evaluate the vertical distribution of dust during the Trans-Atlantic transport, we have calculated the mean vertical profiles over $10^{\circ}$ longitude zones starting from $10^{\circ}$ to $70^{\circ}$ west as shows in Figure 3. These zones were limited between the latitude $10^{\circ} \mathrm{S}$ and $35^{\circ} \mathrm{N}$, since most of the transported dust is located within this range. The analysis was concentrated over the different vertical patterns emerge between winter-spring and summer-autumn. 


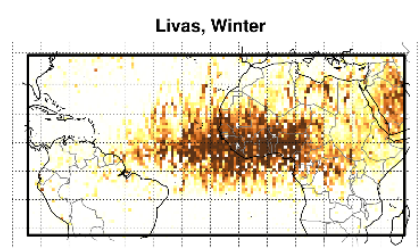

Livas, Spring

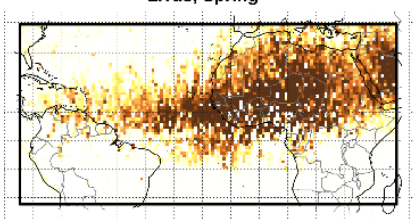

Livas, Summer

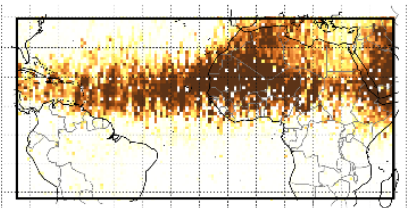

Livas, Autumn

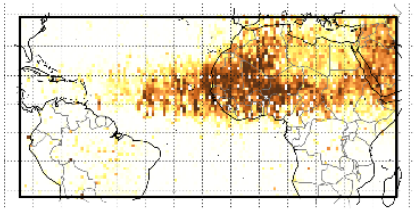

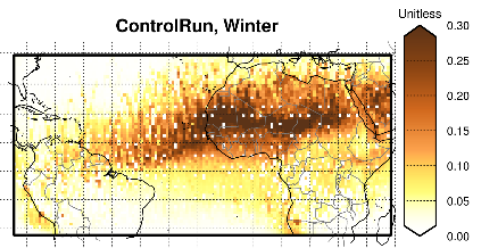

ControlRun, Spring

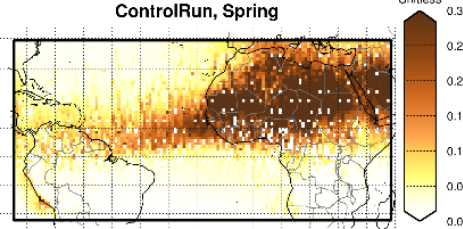

ControlRun, Summer

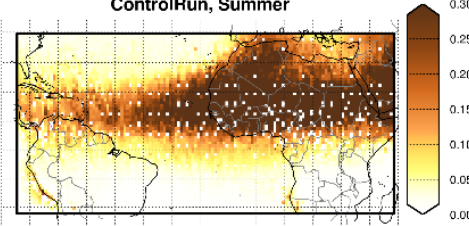

ControlRun, Autumn

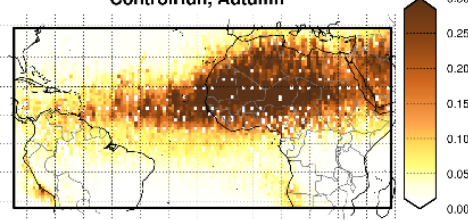

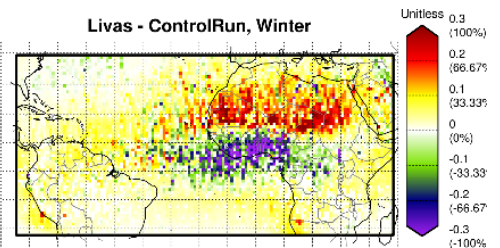

Livas - ControlRun, Spring

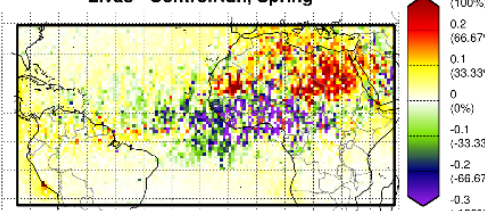

Livas - ControlRun, Summer
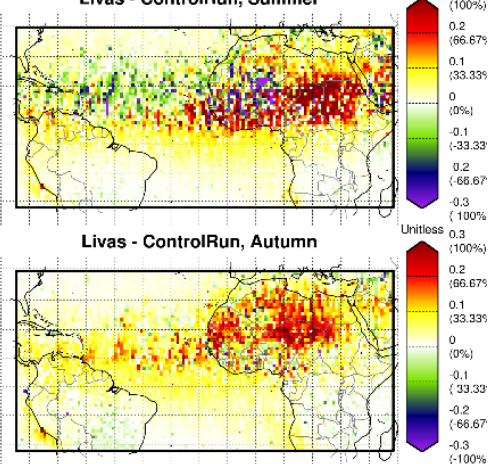

Figure 2 - Dust optical depth for Livas at 532nm and RegCM4 at 550nm for the year 2007. Top to end row winter, spring, summer, autumn are displayed respectively.

Figure 4 and Figure 5 illustrate the vertical DEX distribution and its evolution across the TransAtlantic dust transport in summer-autumn and winter-spring, respectively. Note that the upper row (first 3 plots) depicts the zones closer to the emission sources that bear higher DEX values, since dry deposition which is the dominant removal process for large particles didn't have the time to remove dust from the Atmosphere. The second row, depicts the zones closer to the central and south America, where most of the larger dust particles have been deposited into the Atlantic ocean, reducing therefore the DEX values.

During summer-autumn, RegCM4 simulates remarkably well the vertical distribution of dust on the eastern Atlantic zones. If we exclude the values close to the surface, both the model and the observation show a maximum between 3-4km. The simulated DEX shows a slower decrease with height after the peak value, while LIVAS DEX rapidly declines to almost zero after 5-6km. Consequently, RegCM4 overestimates DEX above 5km, especially in the zones located in the western Atlantic ocean. The displacement of the simulated dust high in the mid-Troposphere may affect greatly the dry and wet deposition processes in the model as well as the trans-Atlantic transfer. In winter-spring the transport takes place in a lower altitude and DEX swiftly reduces from the ground up almost linearly till $5 \mathrm{~km}$. The slower decrease of DEX with height after $5 \mathrm{~km}$ is taking place also winter-spring. According to LIVAS, more than $96 \%$ and $99 \%$ of DEX is found between $200 \mathrm{~m}-5000 \mathrm{~m}$ in summer-autumn and winter-spring respectively. 


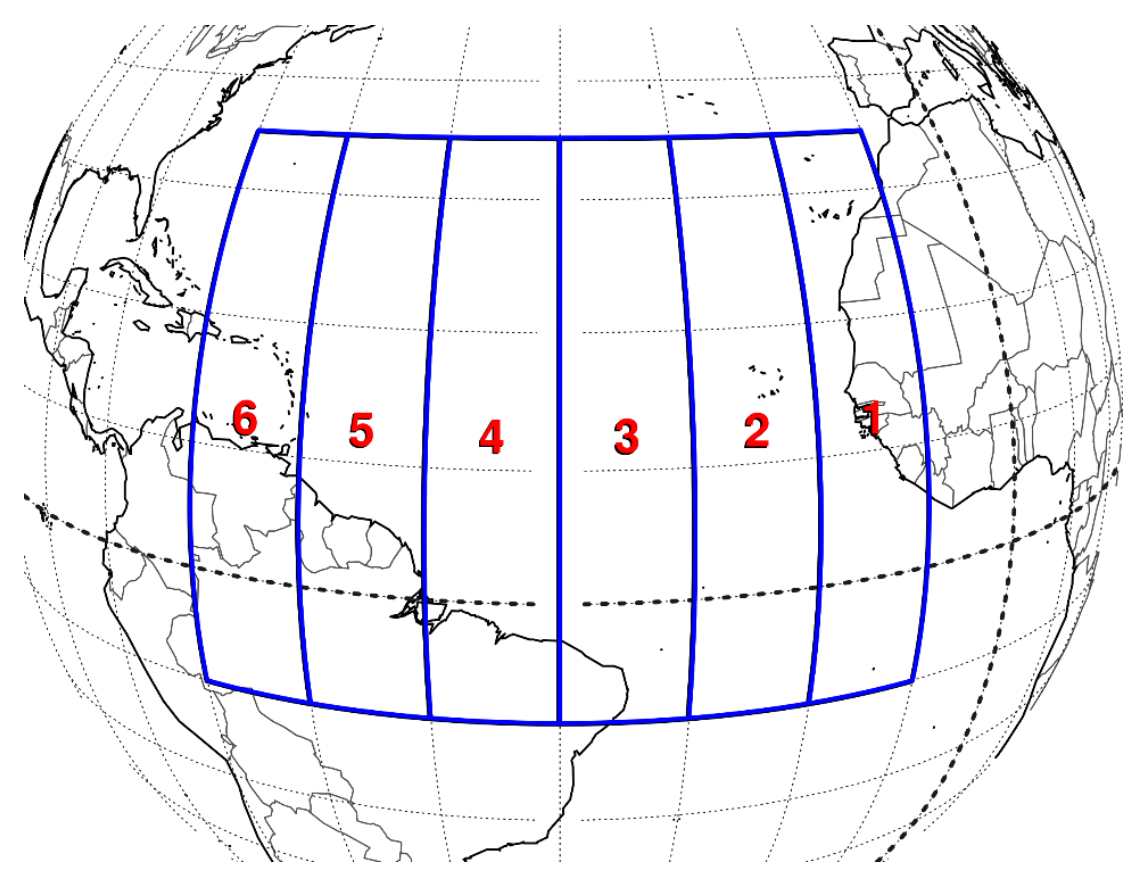

Figure 3 - Subregions where the averaged DEX profiles have been calculated.
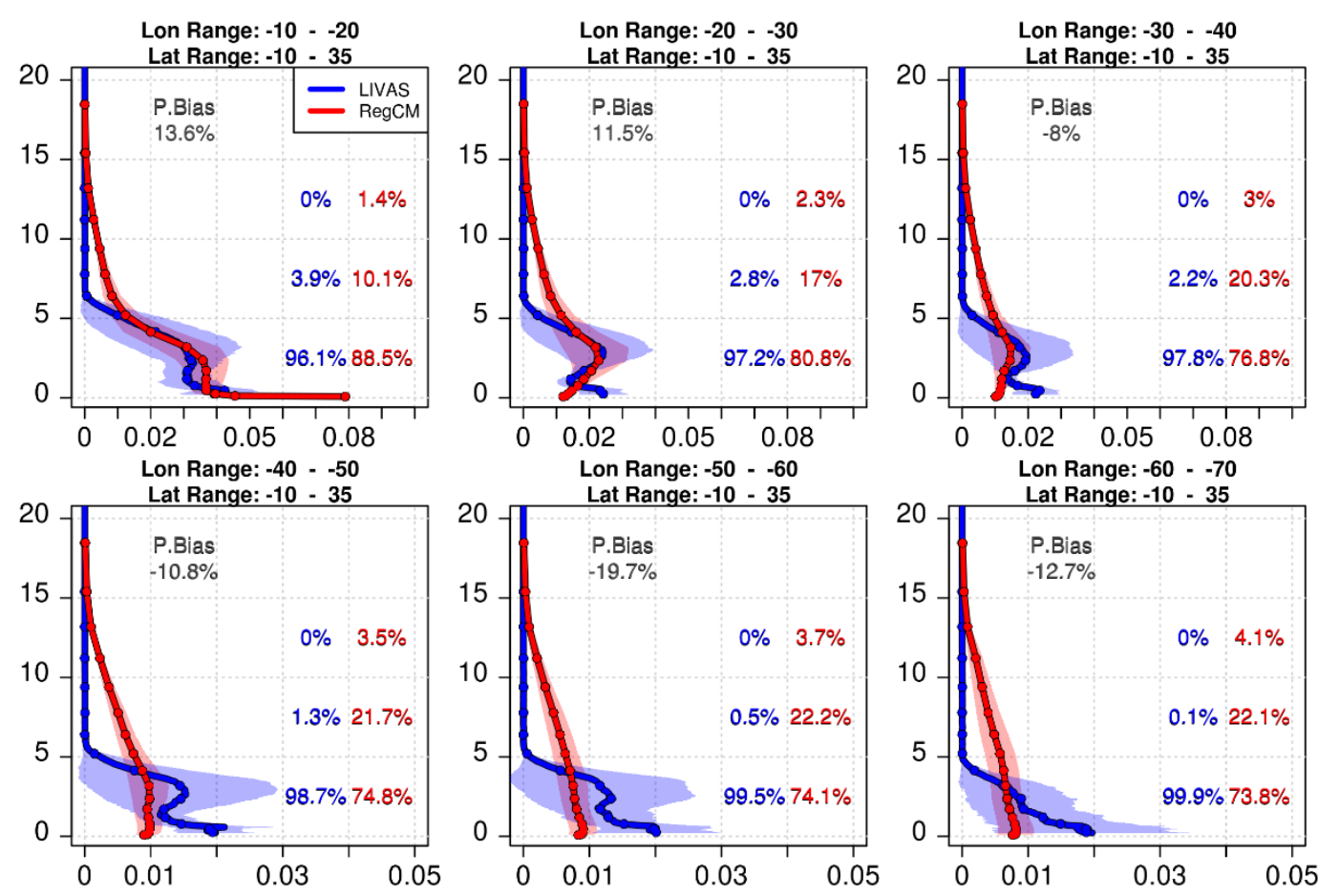

Figure 4 - Summer-autumn vertical column profiles of Dust EXtrinction (DEX) coefficient for averaged regions over the Atlantic. Blue line depicts LIVAS and red RegCM4. The colored percentage numbers present the amount of DEX located between $0-5 \mathrm{~km}, 5-10 \mathrm{~km}$ and $10-20 \mathrm{~km}$ respectively. The percentage bias (P. Bias) is also illustrated on the plot. 

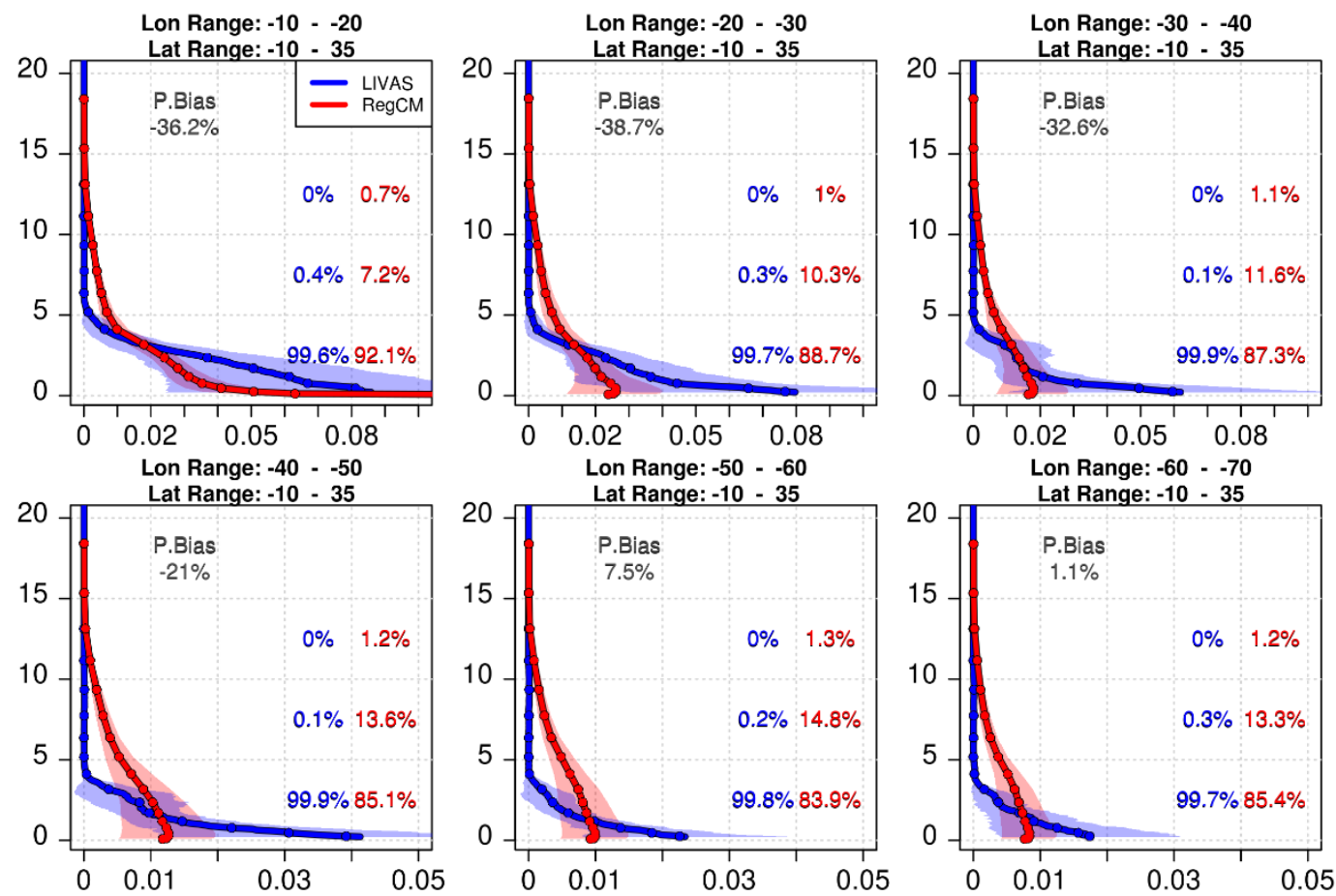

Figure 5 - Winter-spring vertical column profiles of Dust EXtrinction (DEX) coefficient for averaged regions over the Atlantic. Blue line depicts LIVAS and red RegCM4. The colored percentage numbers present the amount of DEX located between $0-5 \mathrm{~km}, 5-10 \mathrm{~km}$ and 10 $20 \mathrm{~km}$ respectively. The percentage bias (P. Bias) is also illustrated on the plot.

\section{Discussion}

Our experiment with RegCM4 can simulate the Trans-Atlantic seasonal transport of dust fairly accurate but it differentiates from LIVAS on some key spatial features especially in winter and spring. The spring southward shift observed in satellite measurements emerges from various independent factors (Prospero et al., 2014). One of these factors is the seasonal changes of the active dust sources in Sahara. Based on a simulation of an offline dust model that uses the re-analysis database ERA-40 and ground-based measurements for several soil characteristics in Sahara, we know that emitted fluxes follow a marked seasonal cycle that peaks in spring over the eastern part of the desert and in summer on the western (Laurent et al., 2008). Eastern dust sources therefore play a major role over the Trans-Atlantic transportation, since most of the dust is produced on that side of the desert. According to DOD, RegCM4 dust production correlates with that spatial-temporal pattern, where western Sahara DOD peaks at summer and eastern at spring. More importantly during spring, the model is over-productive in the eastern Sahara, since it overestimates DOD when compared to LIVAS. Thus, the simulated seasonality of the dust sources in the Eastern Sahara are not responsible for the underestimation of the southward Trans-Atlantic transportation during spring. Nevertheless, this conclusion needs further investigation since it is based on DOD and not in actual emitting fluxes and the seasonality of the active dust sources varies from year to year (Prospero et al., 2002).

A more probable cause for the underestimation of the southern Trans-Atlantic transport during spring-winter from RegCM4 might be the location of the Inter-Tropical Convergence Zone (ITCZ) that correlates with the western Africa monsoon in this area. The ITCZ controls the seasonal precipitation rates over the semi-arid Sahel area and more importantly the changes in large-scale 
wind patterns. Both of these factors affect dust productivity and transport (Engelstaedter et al., 2006; Engelstaedter and Washington, 2007; Williams, 2008).

According to CALIPSO measurements most of the global models underestimate DEX in lower levels close to the sources and overestimates it on higher altitudes above Atlantic (Koffi et al., 2012). Our simulation demonstrates the same behaviour. The vertical uplift of dust is forced by three processes in RegCM4, turbulence, wet convection and general dry advection of the atmosphere. The long-range Trans-Atlantic transport is affected mostly by the last two mechanisms. The Emmanuel convective scheme (Emanuel, 1991) used over ocean in our simulation accounts for vertical transport of aerosol tracers into a cumulus convection. Therefore, if we overestimate cumulus convection over the Atlantic, we might as well overestimate the dust vertical distribution especially in altitudes greater than $5 \mathrm{~km}$. Further research and extended cloud evaluation is necessary to answer this question.

The continuation of this research can be summarized in four steps. (1) Confirm the seasonality of the emitted fluxes from the Sahara desert with the observational data, (2) evaluate the large scale wind and precipitation patterns on our domain (3) investigate the role of in cloud convective uplift on the vertical distribution of dust during transport and (4) calculate the dust loss frequency of the model, which is defined by the ratio of total removal rate to dust load, and compare it with previous studies (Kim et al., 2014).

\section{Conclusion}

RegCM4 is capable of capturing the Trans-Atlantic transport of dust from Sahara towards the SouthCentral America. The model was evaluated with the pure dust satellite product LIVAS. Some localized discrepancies have been found. RegCM4 overestimates the DOD over the eastern Sahara in all seasons, while it underestimates over the gulf of Guinea during winter-spring. A misrepresentation of western Africa monsoon that controls the spatial-temporal evolution of ITCZ as well as the precipitation and the large scale wind patterns might be responsible for these biases. We found that RegCM4 overestimates DEX in altitudes greater than $5 \mathrm{~km}$ in all seasons. On summerautumn the vertical distribution of dust between $3-4 \mathrm{~km}$ during the Trans-Atlantic transportations is simulated by the model adequately till $30^{\circ} \mathrm{W}-40^{\circ} \mathrm{W}$ longitude. However, during winter-spring RegCM4 misplaces dust loading into higher altitude.

\section{References}

Alfaro, S.C., Gaudichet, A., Gomes, L. and Maillé, M., 1997. Modeling the size distribution of a soil aerosol produced by sandblasting, J. Geophys. Res., 102, 11,239-11,249.

Amiridis, V., Marinou, E., Tsekeri, A., Wandinger, U., Schwarz, A., Giannakaki, E., Mamouri, R., Kokkalis, P., Binietoglou, I., Solomos, S., Herekakis, T., Kazadzis, S., Gerasopoulos, E., Proestakis, E., Kottas, M., Balis, D., Papayannis, A., Kontoes, C., Kourtidis, K., Papagiannopoulos, N., Mona, L., Pappalardo, G., Le Rille, O. and Ansmann, A., 2015. LIVAS: a 3-D multi-wavelength aerosol/cloud database based on CALIPSO and EARLINET, Atmos. Chem. Phys., 15, 7127-7153.

Amiridis, V., Wandinger, U., Marinou, E., Giannakaki, E., Tsekeri, A., Basart, S., Kazadzis, S., Gkikas, A., Taylor, M., Baldasano, J. and Ansmann, A., 2013. Optimizing CALIPSO Saharan dust retrievals, Atmos. Chem. Phys., 13, 12089-12106.

Bangert, M., Nenes, A., Vogel, B., Barahona, D., Karydis, V.A, Kumar, P., Kottmeier, C. and Blahak, U., 2012. Saharan dust event impacts on cloud formation and radiation over Western Europe, Atmos. Chem. Phys., 12, 4045-4063.

Bristow, C.S., Hudson-Edwards, K.A. and Chappell, A., 2010. Fertilizing the Amazon and equatorial Atlantic with West African dust, Geophys. Res. Lett., 37, doi: 10.1029/2010GL043486.

Chin, M., Diehl, T., Tan, Q., Prospero, J.M., Kahn, R.A., Remer, L.A., Yu, H., Sayer, A.M., Bian, H., Geogdzhayev, I.V., Holben, B.N., Howell, S.G., Huebert, B.J., Hsu, N.C., Kim, D., Kucsera, 
T.L., Levy, R.C., Mishchenko, M.I., Pan, X., Quinn, P.K., Schuster, G.L., Streets, D.G., Strode, S.A., Torres, O. and Zhao, X.-P., 2014. Multi-decadal aerosol variations from 1980 to 2009: a perspective from observations and a global model, Atmos. Chem. Phys., 14, 3657-3690.

Dickinson, R.E., Henderson-Sellers, A. and Kennedy, P.J., 1993. Biosphere-Atmosphere Transfer Scheme (BATS) Version 1e as Coupled to the NCAR Community Climate Codel, NCAR/TN-387+STR, Boulder, Colorado.

Emanuel, K.A., 1991. A Scheme for Representing Cumulus Convection in Large-Scale Models, $J$. Atmos. Sci., 48, 2313-2329.

Engelstaedter, S., Tegen, I. and Washington, R., 2006. North African dust emissions and transport, Earth-Science Rev., 79, 73-100.

Engelstaedter, S. and Washington, R., 2007. Atmospheric controls on the annual cycle of North African dust, J. Geophys. Res., 112, D03103, doi: 10.1029/2006JD007195.

Foret, G., Bergametti, G., Dulac, F. and Menut, L., 2006. An optimized particle size bin scheme for modeling mineral dust aerosol, J. Geophys. Res., 111, D17310, doi: 10.1029/2005JD006797.

Formenti, P., Schütz, L., Balkanski, Y., Desboeufs, K., Ebert, M., Kandler, K., Petzold, A., Scheuvens, D., Weinbruch, S. and Zhang, D., 2011. Recent progress in understanding physical and chemical properties of African and Asian mineral dust, Atmos. Chem. Phys., 11, 8231-8256.

Giorgi, F., Coppola, E., Solmon, F., Mariotti, L., Sylla, M.B., Bi, X., Elguindi, N., Diro, G.T., Nair, V., Giuliani, G., Turuncoglu, U.U., Cozzini, S., Güttler, I., O’Brien, T.A., Tawfik, A.B., Shalaby, A., Zakey, A.S., Steiner, A.L., Stordal, F., Sloan, L.C. and Brankovic, C., 2012. RegCM4: model description and preliminary tests over multiple CORDEX domains, Clim. Res., 52, 7-29.

Giorgi, F., Huang, Y., Nishizawa, K. and Fu, C., 1999. A seasonal cycle simulation over eastern Asia and its sensitivity to radiative transfer and surface processes, J. Geophys. Res., 104, 6403-6423.

Gong, S.L., 2003. Characterization of soil dust aerosol in China and its transport and distribution during 2001 ACE-Asia: 2. Model simulation and validation, J. Geophys. Res., 108, 4262, doi: 10.1029/2002JD002633.

Huneeus, N., Schulz, M., Balkanski, Y., Griesfeller, J., Prospero, J., Kinne, S., Bauer, S., Boucher, O., Chin, M., Dentener, F., Diehl, T., Easter, R., Fillmore, D., Ghan, S., Ginoux, P., Grini, A., Horowitz, L., Koch, D., Krol, M.C., Landing, W., Liu, X., Mahowald, N., Miller, R., Morcrette, J.-J., Myhre, G., Penner, J., Perlwitz, J., Stier, P., Takemura, T. and Zender, C.S., 2011. Global dust model intercomparison in AeroCom phase I, Atmos. Chem. Phys., 11, 7781-7816.

Kaufman, Y.J., 2005. Dust transport and deposition observed from the Terra-Moderate Resolution Imaging Spectroradiometer (MODIS) spacecraft over the Atlantic Ocean, J. Geophys. Res., 110, D10S12, doi: 10.1029/2003JD004436.

Kiehl, J.T., Hack, J.J. and Bonan, G.B., 1996. Description of the NCAR Community Climate Model (CCM3), National Center for Atmospheric Research, Boulder, Colorado.

Kim, D., Chin, M., Yu, H., Diehl, T., Tan, Q., Kahn, R.A., Tsigaridis, K., Bauer, S.E., Takemura, T., Pozzoli, L., Bellouin, N., Schulz, M., Peyridieu, S., Chedin, A. and Koffi, B., 2014. Sources, sinks, and transatlantic transport of North African dust aerosol: A multimodel analysis and comparison with remote sensing data, J. Geophys. Res. Atmos., 119, 6259-6277.

Knippertz, P. and Stuut, J.-B.W., 2014. Mineral Dust, doi: 10.1007/978-94-017-8978-3.

Koffi, B., Schulz, M. and Bréon, F.-M., 2012. Application of the CALIOP layer product to evaluate the vertical distribution of aerosols estimated by global models: AeroCom phase I results, $J$. Geophys. Res., 117, D10201, doi: 10.1029/2011JD016858.

Koren, I., Kaufman, Y.J., Washington, R., Todd, M.C, Rudich, Y., Martins, J.V. and Rosenfeld, D., 2006. The Bodélé depression: a single spot in the Sahara that provides most of the mineral dust to the Amazon forest, Environ. Res. Lett., 1, 014005. doi: 10.1088/1748-9326/1/1/014005.

Laurent, B., Marticorena, B., Bergametti, G., Leon, J.F. and Mahowald, N.M., 2008. Modeling mineral dust emissions from the Sahara desert using new surface properties and soil database, J. Geophys. Res., 113, D14218, doi: 10.1029/2007JD009484.

LIVAS, 2013. LIVAS Lidar Climatology of Vertical Aerosol Structure for Space-Based Lidar Simulation Studies, Final Report Submitted: ESTEC Contract No. 4000104106/11/NL/FF/fk. 1-211. 
Mahowald, N., Albani, S., Kok, J.F., Engelstaederc, S., Scanzaa, R., Warda, D.S. and Flannerd, M.G., 2014. The size distribution of desert dust aerosols and its impact on the Earth system, Aeolian Res., 15, 53-71.

Mahowald, N.M., Baker, A.R., Bergametti, G., Brooks, N., Duce, R.A., Jickells, T.D., Kubilay, N., Prospero, J.M. and Tegen, I., 2005. Atmospheric global dust cycle and iron inputs to the ocean, Global Biogeochem. Cycles, 19 n/a-n/a, doi: 10.1029/2004GB002402.

Marticorena, B. and Bergametti, G., 1995. Modeling the atmospheric dust cycle: 1. Design of a soilderived dust emission scheme, J. Geophys. Res., 100, 16415-16430.

Mlawer, E.J. and Clough, S.A., 1997. On the Extension of Rapid Radiative Transfer Model to the Shortwave Region Longwave Method and. U.S. Department of Energy, CONF-9603149.

Mlawer, E.J., Taubman, S.J., Brown, P.D., Iacono, M.J. and Clough, S.A., 1997. Radiative transfer for inhomogeneous atmospheres: RRTM, a validated correlated-k model for the longwave, J. Geophys. Res., 102, 16663-16682.

Oleson, K.W., Lawrence, D.M., Bonan, G.B., Flanner, M.G., Kluzek, E., Lawrence, P.J., Levis, S., Swenson, S.C., Thornton, P.E., Dai, A., Decker, M., Dickinson, R., Feddema, J., Heald, C.L., Hoffman, F., Lamarque, J.-F., Mahowald, N., Niu, G.-Y., Qian, T., Randerson, J., Running, S., Sakaguchi, K., Slater, A., Stockli, R., Wang, A., Yang, Z.-L., Zeng, Xi. and Zeng, Xu., 2010. Technical Description of version 4.0 of the Community Land Model (CLM). NCAR Technical Note NCAR/TN-478+STR, National Center for Atmospheric Research, Boulder, CO, 257 pp.

Prospero, J.M., Collard, F.-X., Molinié, J. and Jeannot, A. 2014. Characterizing the annual cycle of African dust transport to the Caribbean Basin and South America and its impact on the environment and air quality, Global Biogeochem. Cycles, 28, 757-773.

Prospero, J.M., Ginoux, P., Torres, O., Nicholson, S.E. and Gill, T.E., 2002. Environmental characterization of global sources of atmospheric soil dust identified with the NIMBUS 7 Total Ozone Mapping Spectrometer (TOMS) absorbing aerosol product, Rev. Geophys., 40, 2, 1-2, 31.

Ridley, D.A., Heald, C.L. and Ford, B., 2012. North African dust export and deposition: A satellite and model perspective, J. Geophys. Res., 117, D02202, doi: 10.1029/2011JD016794.

Schuster, G.L., Vaughan, M., MacDonnell, D., Su, W., Winker, D., Dubovik, O., Lapyonok, T. and Trepte, C., 2012. Comparison of CALIPSO aerosol optical depth retrievals to AERONET measurements, and a climatology for the lidar ratio of dust, Atmos, Chem. Phys., 12, 7431-7452.

Solmon, F., Giorgi, F. and Liousse, C., 2006. Aerosol modelling for regional climate studies: application to anthropogenic particles and evaluation over a European/African domain, Tellus B, 58, 51-72.

Tegen, I., 2003. Modeling the mineral dust aerosol cycle in the climate system, Quat. Sci. Rev., 22, 1821-1834.

Williams, E.R., 2008. Comment on "Atmospheric controls on the annual cycle of North African dust" by S. Engelstaedter and R. Washington, J. Geophys. Res., 113, D23109, doi: 10.1029/2008JD009930.

Winker, D.M., Vaughan, M.A., Omar, A.H., Hu, Y., Powell, K.A., Liu, Z., Hunt, W.H. and Young, S.A., 2009. Overview of the CALIPSO Mission and CALIOP Data Processing Algorithms, J. Atmos. Oceanic Technol., 26, 2310-2323.

Yu, H, Chin, M., Bian, H., Yuan, T., Prospero, J.M., Omar, A.H., Remer, L.A., Winker, D.M., Yang, Y., Zhang, Y. and Zhang, Z., 2015. Quantification of trans-Atlantic dust transport from seven-year (2007-2013) record of CALIPSO lidar measurements, Remote Sens. Environ., 159, 232-249.

Zakey, A.S, Solmon, F. and Giorgi, F., 2006. Implementation and testing of a desert dust module in a regional climate model, Atmos. Chem. Phys., 6, 4687-4704.

Zipser, E.J., Twohy, C.H., Tsay, S.C., Thornhill, K.L., Tanelli, S., Ross, R., Krishnamurti, T.N., Ji, Q., Jenkins, G., Ismail, S., Hsu, N.C., Hood, R., Heymsfield, G.M., Heymsfield, A., Halverson, J., Goodman, H.M., Ferrare, R., Dunion, J.P., Douglas, M., Cifelli, R., Chen, G., Browell, E.V. and Anderson, B., 2009. The Saharan Air Layer and the fate of African Easterly Waves-NASA's AMMA field study of tropical cyclogenesis, Bull. Amer. Meteor. Soc., 90, 1137-1156. 